Citation: İncikab1, S. \& Biber, A. (2021). Process of designing model eliciting activities in mathematics teaching. International Journal of Scholars in Education, 4(1), 97-118. doi:10.52134/ueader.910493

\title{
Process of Designing Model Eliciting Activities in Mathematics Teaching
}

\author{
Semahat İNCIKKABI*, Abdullah BİBER**
}

\begin{abstract}
The aim of this study is to analyze prospective mathematics teachers' (PMT) process of designing model eliciting activities. Case study was preferred in this study. The study group of this research consists of 15 mathematics prospective mathematics teachers studying at Kastamonu University Faculty of Education Primary Mathematics Teaching Undergraduate Program during the academic year of 2019-2020. In this research, learning environments designed based on a holistic approach and based on "theoretical knowledge" were created. The research process took 10 weeks which are planned as mathematical modeling training process and model eliciting activity (MEA) design process. Data of the study were collected through MEA design process worksheets. The data obtained from the data collection tool were subjected to content analysis. As a result of the research, it was determined that PMT groups included similar processes although there were some differences in the MEA design stages. The writing stages proceeded as determining the context of the MEA, deciding on variables and assumptions, writing the scenario and adding visual elements. In the control phase, the elements that the groups pay attention to include compliance with MEA principles, text control, visual editing, performing solution steps (model and data compatibility).
\end{abstract}

Keywords: Model eliciting activities, Mathematical modelling, Prospective mathematics teacher education.

\section{Matematik Öğretiminde Model Oluşturma Etkinlikleri Tasarım Sürecinin İncelenmesi}

Öz: $\mathrm{Bu}$ çalışmanın amacı, matematik öğretmen adaylarının model oluşturma etkinlikleri tasarlama sürecini incelemektir. Bu çalışmada örnek olay incelemesi tercih edilmiştir. Bu araştırmanın çalışma grubunu Kastamonu Üniversitesi Eğitim Fakültesi İlköğretim Matematik Öğretmenliği Lisans Programında 2019-2020 eğitim öğretim y1lında öğrenim gören 15 matematik öğretmeni aday1 oluşturmaktadır. Bu araştırmada, bütüncül bir yaklaşımla tasarlanan ve "teorik bilgi" esas alınarak tasarlanan öğrenme ortamları oluşturulmuştur. Matematiksel modelleme eğitim süreci ve model oluşturma etkinlikleri tasarım süreci olarak planlanan araştırma süreci 10 hafta sürmüştür. Araştırmanın verileri model oluşturma etkinlikleri tasarım süreci çalışma yaprakları aracılığıyla toplanmıştır. Veri toplama aracından elde edilen veriler içerik analizine tabi tutulmuştur. Araştırma sonucunda, model oluşturma etkinlikleri tasarım aşamalarında bazı farklılıklar olsa da, grupların benzer süreçleri içerdiği tespit edilmiştir. Yazma aşamaları gene olarak model oluşturma etkinliklerinin bağlamının belirlenmesi, değişkenlere ve varsayımlara karar verilmesi, senaryo yazılması ve görsel unsurların eklenmesi şeklinde ilerlemiştir. Kontrol aşamasında grupların dikkat ettiği unsurlar arasında model oluşturma etkinlikleri tasarım ilkelerine uyum, metin kontrolü, görsel düzenleme, çözüm adımlarının gerçekleştirilmesi (model ve veri uyumluluğu) yer almıştır.

Anahtar Kelimeler: Model oluşturma etkinlikleri, Matematiksel modelleme, Matematik öğretmen aday1 eğitimi.

\footnotetext{
* Ph.D, ORCID: 0000-0002-7686-1996, e-mail: agdassemahat@ yahoo.com

** Ph.D, Kastamonu University, Education Faculty, ORCID: 0000-0001-7635-3951, e-mail:

acbiber@kastamonu.edu.tr
} 


\section{Introduction}

The concept of mathematical modeling and related skills have been found important from the past to the present, and teaching programs have been included in their general goals (Blomhoj \& Kjeldsen, 2006; NCTM, 1989, 2000; Niss, Blum, \& Galbraith., 2007). National Council of Teachers of Mathematics (NCTM) emphasized the importance of using mathematical modeling in problem solving and stated that mathematical modelling contributes on making sense of the relationships between the concepts (NCTM, 2000). The concept of modeling entered the general objectives of mathematics education in 2005 for the first time in the mathematics curriculum in Turkey, and it was aimed to equip students in a way to "establish models and associate models with verbal and mathematical expressions" (Ministry of National Education-MoNE, 2005). Moreover, the importance of starting the teaching process of learning mathematics with concrete experiences and using mathematical models in this process was pointed out. Mathematical modeling was considered as a basic mathematical skill in the Turkish mathematics curriculum of 2017. The current mathematics teaching program in Turkey also emphasizes the ability of students to make mathematical modeling through the implementation of activities that improve the mathematical modeling competencies of teachers in the mathematics teaching process (MoNE, 2017). The development of mathematical modeling skills of students, which is emphasized in national and international programs, is only possible if teachers have modeling competencies. In this direction, it is important to carry out modeling competence practices in faculties that train teachers and to plan undergraduate / graduate level courses. In addition, it is important to check the prospective teachers' ability to develop their modeling competence in the planned practices and to examine the potential of pre-service teachers to use these competencies in classrooms.

Despite the emphasis on the importance of mathematical modeling in curricula, both national and international studies show that students cannot use their mathematical knowledge at the desired level in real life contexts (Arcavi, 2002; Baki \& Aydın-Güç, 2014a, Busse, 2005; Umay, 2003; Vinner, 2007). Mathematical modeling competencies should be developed in order for students to produce solutions to real life problems they encounter with their mathematical knowledge (Baki \& Aydın-Güç, 2014b; Busse, 2011; Maßß, 2006). Studies show that mathematical modeling can be taught and learned, and individuals who receive training for mathematical modeling are more successful in mathematical modeling (Ferri \& Blum, 2013; Özer Keskin, 2008). In this context, in order to improve students' mathematical modeling skills, the teaching in teacher education should be designed to develop these skills, and activities should be prepared accordingly (Vorhölter, Kaiser, \& Ferri, 2014). Therefore, learning environments should be designed in in-service and pre-service programs to improve the mathematical modeling competencies of teachers and pre-service teachers (Aydın Güç, 2015). When the literature is examined, although there are many articles and theses on teacher education in studies on mathematical modeling, there are a limited number of studies examining the design processes in which these skills turn into practice with the education given to prospective mathematics teachers. In these studies, instead of examining the MEA processes, the conformity of the MEAs prepared with the basic principles of MEA was evaluated (e.g., Tekin Dede \& Bukova Güzel, 2013a, 2013b).

In line with the above explanations, the aim of this study is to examine the model eliciting activity (MEA) design processes of elementary mathematics prospective mathematics teachers upon enrolling in the mathematical modeling training. For this purpose, the research problem was "Which stages did the prospective mathematics teachers follow in the process of designing MEA?" determined as. 


\section{Model Eliciting Activities in Mathematics}

The definition of model eliciting activities is influenced by the perspectives on the intended use. For this, first of all, it is necessary to discuss the difference between practice and mathematical modeling activities. The so-called practice activities are focused on the transition from mathematics to the real world. The model has already been learned and built. In such activities, the answer to the question "Where can I use this part of mathematical knowledge?" is sought (Stillman, 2012). In mathematical modeling, the focus is on mathematics from the real world. The mathematical model is built through the mathematization and specification and idealization of the real life situation. In such activities, the answer to the question "Where can I find the math that can help me solve this problem?" is sought (Stillman, 2012). Both types of activities find their way into the classroom. Since the aim of this study is to provide students with the competencies that can solve the problems they will encounter in real life, the current study discusses the mathematical modeling activities to find an answer to the question "Where can I find the math that will help me?" to seek for a solution of problems encountered in real life.

Although the definitions of mathematical modeling made by different researchers are handled within the same framework, mathematical modeling has different interpretations when used in curriculum discussions and applications (Stillman, 2012). Therefore, mathematical modeling activities are also affected by different perspectives. While one perspective considers mathematical modeling as a tool that shows the relationship of certain mathematical content, develops it and provides motivation (Chinnappan, 2010), another perspective considers mathematical modeling as a goal rather than a tool for the realization of mathematical learning (Blomhoj \& Jensen, 2007). While the model and modeling approach defined by Lesh and Doerr (2003) is directly related to the first point of view, it provides a wider perspective to mathematical modeling by including the elements of the second perspective in the content. In other words, while mathematical modeling is a tool for teaching mathematical concepts, there are some mathematical modeling competencies that need to be acquired. Lesh and Doerr (2003) call such activities "model eliciting activities (MEA)" that include both process and model. Stillman (2012), on the other hand, takes his own point of view as the second perspective that includes the first point of view. That is, mathematical modeling is a goal, but while achieving this goal, some mathematical concepts can be taught. In this study, the perspective defined by Stillman (2012) was adopted. In this context, in this study, mathematical modeling was considered as the purpose of mathematics education and opportunities were provided for the learning or expansion of some mathematical concepts without moving away from the concepts to be learned in mathematics education. These types of activities can be called MEA because they are both process and model oriented.

For the first time, Lesh, Hoover, Hole, Kelly and Post (2000), instead of being an activity in which real-world problem scenarios are presented and students need to create a model that solves the problem situation, they are also defined as math-based activities that require them to develop a model that can be generalized to other contexts (Lesh \& Harel, 2003). Similarly, modeling activities are defined as problem-solving activities created by using certain principles of instructional design in which students make logical inferences, invent, expand and develop their own mathematical structures (Kaiser \& Sriraman, 2006). MEAs provide two different opportunities for students. The first is to apply the information they have already learned, and the second is to enable them to understand mathematical subjects more deeply by mathematizing real-life situations (Yoon, Dreyfus, \& Thomes, 2010). In this study, mathematical modeling activities were accepted as activities that allow students to go through the whole process of mathematical modeling by using the knowledge they have already learned, and to expand or make sense of their past learning by mathematizing the real life problem. 
MEAs are defined as math-based activities that require students to develop a model that can be generalized to other contexts, rather than being an activity in which real-world problem scenarios are presented and students need to create a model that only serves to solve the problem situation (Lesh \& Harel, 2003). Similarly, modeling activities are defined as problemsolving activities created by using certain principles of instructional design in which students make logical inferences, invent, expand and develop their own mathematical structures (Kaiser \& Sriraman, 2006). MEAs provide two different opportunities for students. The first is to apply the information they have already learned, and the second is to enable them to understand mathematical subjects more deeply by mathematizing real-life situations (Yoon et al., 2010). In this study, MEAs were accepted as activities that allow students to go through the whole process of mathematical modeling by using the knowledge they have already learned, and to expand or make sense of their past learning by mathematizing the real life problem.

\section{Methodology}

The case study approach, one of the qualitative research methods, was used in this study. According to McMillan (1996), this type of research is a method used to examine in depth the ties between one or more events, settings, programs, social groups or other interconnected systems.

\section{Participants}

The working group of this research consists of 15 mathematics prospective mathematics teachers studying in the fourth grade of the Kastamonu University Faculty of Education Elementary Mathematics Education Undergraduate Program in the fall and spring terms of the 2019-2020 academic year. The study was conducted within the scope of Elective II and Teaching Practice courses. The reason for choosing senior prospective mathematics teachers who are studying in the Primary Mathematics Education Undergraduate Program is that the students have completed the courses on the mathematical concepts and pedagogical processes required to complete the MEAs discussed in this study. Mathematical modeling training process included working in groups. It was stated to the groups that it was important for the research to attend the courses, and that their group work during the lesson would be evaluated within the scope of the research.

\section{Procedures of the Study}

The training process took 10 weeks. This process was planned as mathematical modeling education and MEA design process. This process was carried out in the fourth grade Elective II (3 lessons per week and 45 minutes per lesson) in the fall semester of the primary school mathematics teaching program. The activities in the designed learning environment are presented within the guidelines in the process of providing theoretical information. The guidelines are designed to give students experience of modeling competencies and organize their work. After the completion of the theoretical knowledge courses, students have been started to work with free MEAs that do not contain any instructions for the mathematical modeling process. In the designed learning environment, prospective mathematics teachers worked on MEAs in groups. Afterwards, each group was asked to enter the MEA design process. There were no restrictions regarding the content of the said MEA, only they were asked to pay attention to the MEA to be suitable for a selected grade level in secondary education and to be directed to the subject / subjects they chose from this grade level.

At the end of the group work, each group presented the MEA design they formed, class discussions were held and their designs were edited when deemed necessary by the groups. In 
the learning environment, students are provided with the opportunity to go out of the classroom to do research whenever they want, to do the research they want using a computer in the classroom, and to consult an expert. In this research, the learning environment designed with a holistic approach is aimed at improving mathematical modeling competencies. In this learning environment, in order to guide the participant's process of developing mathematical modeling competencies, MEAs, which are embedded in the instructions of mathematical modeling competencies that are expected to occur and direct the actions that require competencies, were used. MEAs that do not contain these instructions in their design have also been re-designed. In the selection of MEAs, attention has been paid to the fact that prospective mathematics teachers include contexts that they are familiar with but are not very involved in.

Table 1

Application Processes of the Study

\begin{tabular}{|c|c|}
\hline Week & Objective \\
\hline Week 1 & Getting acquainted and explaining the process \\
\hline Week $2 \& 3$ & Theoretical knowledge process \\
\hline Week 4 \& 5 & $\begin{array}{l}\text { Solution of modeling problems under Borromeo Ferri cognitive perspectives according } \\
\text { to modeling competencies } \\
\circ \text { Bed problem (Borromeo-Ferri, 2014) } \\
\bigcirc \text { Adenuar problem (Herget, Jahnke, \& Kroll, 2001) } \\
\bigcirc \text { Population forecast (Ural, 2014) } \\
\bigcirc \text { Giant's boat (Ural, } 2018 \\
\circ \text { Big foot problem (Tekin Dede \& Bukova Güzel (2011), adapted from Lesh } \\
\text { and Doerr (2003)) } \\
\circ \text { Height-foot length problem (Hıdıroğlu \& Bukova Güzel, 2014) } \\
\circ \text { Pisa tower problem (Bukova Güzel, Tekin Dede, Hidıroğlu, Kula Ünver, \& } \\
\text { Özaltun Çelik (2016), adapted from Dede, Hidıroglu \& Güzel (2017)). } \\
\circ \text { Fuel problem (Bukova Güzel et al. (2016), designed from Tekin (2012)) } \\
\circ \text { Ancient theatre problem (Tekin, Hidıroğlu, \& Bukova Güzel, 2010) }\end{array}$ \\
\hline Week 6 & $\begin{array}{l}\text { Defining and discussing the basic principles of mathematical modeling problems: } \\
\circ \text { Reality principle } \\
\circ \text { Model Construction Principle } \\
\circ \text { Self-Assessment Principle } \\
\circ \text { Construct Documentation Principle } \\
\circ \text { Model Generalization Principle } \\
\circ \text { Effective Prototype Principle } \\
\text { Examination and discussion of theses and articles that evaluate Mathematical } \\
\text { Modeling Activities in terms of principles }\end{array}$ \\
\hline Week 7 & Group decision process on determination of groups and subject of MEA \\
\hline Week 8 & Continuation of the MEAs design process - Application of worksheets \\
\hline Week 9 & Continuation of the MEAs design process - Application of worksheets \\
\hline Week 10 & Presentation of MEAs \\
\hline
\end{tabular}

\section{Data Collection Tool}

In the study, worksheets of designing MEA were used as data collection tools. During the preparation of the worksheet, related literature was analyzed, and expert opinions were collected in order to ensure validity. Worksheets were provided to the groups to explain the modeling activities design processes. In the worksheet, explanations were requested for the process of creating a modeling activity, planning, decision-making and criteria, problem posing and control / verification stages (Appendix 1). 


\section{Data Analysis}

Content analysis was used in the analysis of the data obtained from the MEA design process worksheets. Content analysis is an analysis process that requires a more detailed examination of the collected data and reaching the concepts, categories and themes that explain these data (Bengtsson, 2016; Crabtree \& Miller, 1999; Merriam \& Grenier, 2019). Data obtained through interviews, observations or documents in content analysis are analyzed in four stages: (1) coding the data, (2) finding codes, categories and themes, (3) organizing codes, categories and themes, (4) defining and interpreting the findings. (Eysenbach \& Köhler, 2002; Miles \& Huberman, 1994). The data obtained through content analysis from the worksheets were used to detail, record and analyze the design processes of modeling activities. Content analysis was used in the worksheet to analyze the explanations for the process of creating a modeling activity, planning, decision-making and criteria, problem posing and control / verification stages. Findings are tabulated as themes and sub-themes and supported with sample quotations.

\section{Validity and Reliability}

There are different definitions, perspectives and control processes regarding validity in qualitative research. For example, Creswell and Plano Clark (2011) defined validity as an attempt to evaluate the accuracy of the findings. In research, external audit ensures that the research process is controlled from outside (Glesene \& Peshkin, 1992; Guba \& Lincoln, 2004; Merriam, 1988). In this research process, the validity of the process was increased by asking examinations from different studies (field experts and peer researchers) during the decisionmaking process of the research, during the analysis and the interpretation of the findings. According to Creswell (2013), it is important to encode the transcribed data by multiple coders and to provide consensus among coders in order to ensure reliability. Coding was done by one of the researchers of this study and an expert who conducted research on the mathematical modeling competencies process. The percentage of agreement between the analyzes was determined using the calculation proposed by Miles and Huberman (1994). Re-analyzes were made on the topics that were not compatible, and consensus was reached as a result of the discussions.

As a result of the coding of the data obtained from the worksheets, the compliance percentage was calculated as $81 \%$. Miles and Huberman (1994) emphasize that for a good qualitative reliability, the reliability of the coding should be at the level of at least $80 \%$ compliance. In this context, it was seen that the reliability between coders was sufficient in the study. While presenting the findings of the study, the themes (and sub-themes, if any) obtained in each data collection tool were explained in detail, supported by relevant quotations (Patton, 2002).

\section{Ethical Issues}

All participants volunteered to participate in the study. In the research, there was no harmful practice in any way for the participants. During the research, the same information was provided to each participant about the research processes and their personal information was kept confidential. 


\section{Findings}

\section{PMTs' process of designing a MEA}

Findings regarding the PMTs process of designing MEAs were analyzed in line with the planning, activity determination, writing and control processes and the findings are presented below.

\section{Walking death (WD) group MEA design process}

WD group activity is given in Appendix 2. The stages of the WD group for the MEA design process are given in Figure 1. They emphasized that the planning of such a design process should focus on being related to daily life, attractiveness, MEA steps and basic principles of MEA. It is understood that the ÖY group is planning to enter into the research process for such an activity with the statement "... We will take care to make the problems that we will research and write more interesting, such as current issues and games that may be of interest to current generations". They stated that the activities should show problem features and should be "confusing and complicated" in their own words. In line with this, they stated that they wanted an activity that included "the story part is clear [understandable] but having a little word crowd with small details ". They also pointed out the importance of small details to be included in the activities.

They stated that the WD group focused on the subject first when the MEA writing process was examined. WD group focused on determining the subject and the relationship between daily life contexts. "We thought of writing a PIZZA question, which we decided to be suitable for the interests and tastes of children, in order to reconcile it with real life." After that, the market research process started as a group. "We made material and product analysis as a group. ... We determined the price of the ingredients for pizza from the markets. " After the market research process, the process of determining the variables that will detail the problem and make it "complicated" in its own terms and visualizing these variables with the table in the MEA expression were realized. Afterwards, they stated that they shared their own solutions to the problem in the online communication environment they created and that they corrected the deficiencies. After this writing stage, the control process as a group started. In this process, the elements they focused on included compliance with MEA principles, student relativity, text control, developing / adding visual elements. "During the control phase, we evaluated our question according to the principles. ... We examined the difficulty level for the student.... We took out some sentences. We added visuals and ended our control. " The statement summarizes the control process of the WD group.

When the MEA activity, names as Let's Eat Pizza, prepared by the WD group is analyzed in the context of modeling principles, the lunch determination scenario (Appendix 2) between the mother and the child in the problem situation was evaluated as a situation that students may encounter in their real lives. However, in order to make the problem more complicated, it has damaged the compliance of the concept of "gluten-free pizza", which is not encountered in Kastamonu context, with the reality principle. Accordingly, this activity was found partially appropriate in the context of the reality principle. According to the model construction principle, the statement in the problem situation of MEA should be used to create a model and the model should be used in the solution process. Although there is no expression such as "create a model" in the MEA activity, "Can make the right decision in terms of both cost and compliance with the criteria, which option he chooses?" The statement requires students to use a model in the solution. It was therefore considered partially suitable. 


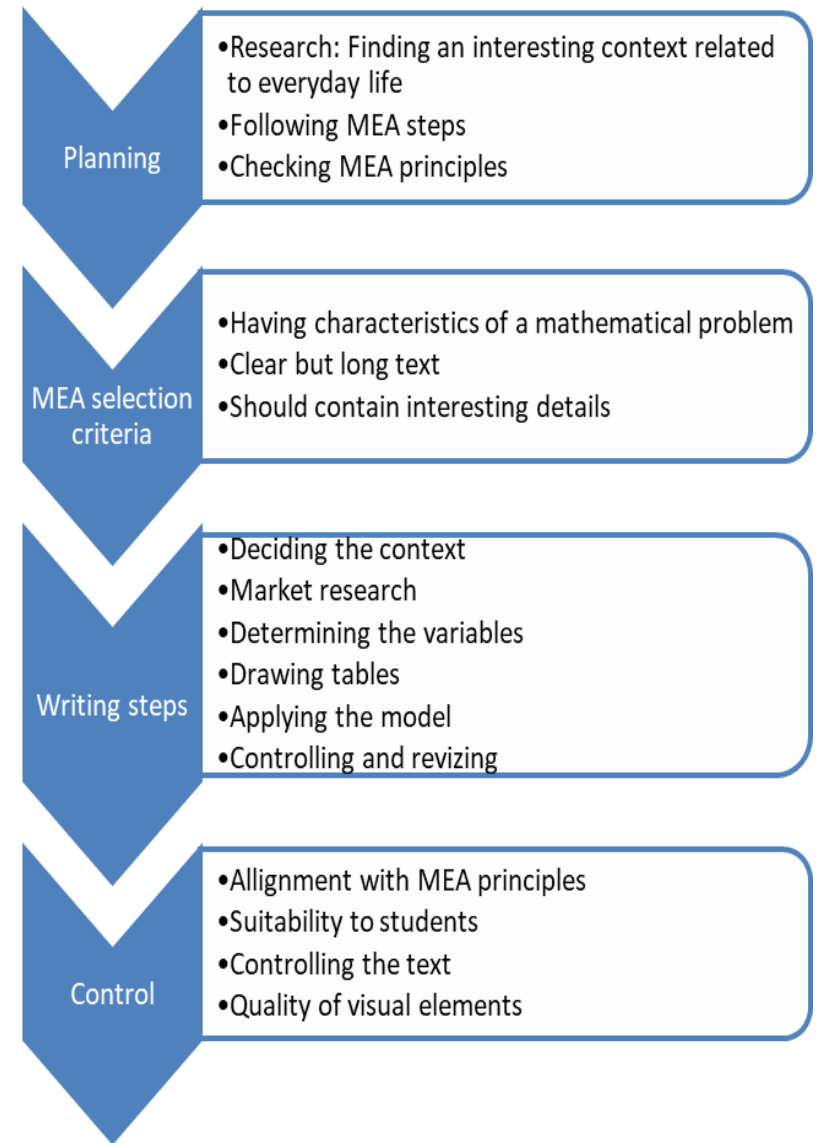

Figure 1. The walking death group MEA design process

It is a deficiency that there is no statement that will enable students to evaluate their own thinking approaches in the situation that is designed as a result of examining the compliance of MEA activity with the self-assessment principle. On the other hand, expressions in the problem situation of MEA have been provided with clear and sufficient data to enable students to make decisions about the process within the group without getting support from their teachers. In this regard, pizza MEA design has been considered appropriate to some extent in the context of the self-assessment principle. In the principle of construct documentation, it is expected that the statements of MEA in the case of a problem will present all the thoughts of the students regarding the solution process in a way that the client / client can understand. In the design of the WD group, one of the students' ... makes the right decision? Explain" statement is found, but since it is not requested to be written so as to present a document to the relevant unit or person, it has been evaluated to be somewhat appropriate in the context of the construct documentation principle. The model generalization principle involves the fact that the statements in problem situations of MEA lead students to create a generalizable model. Since the model to be used in the problem can be used by others in similar situations, the model is completely compatible with the generalization principle.

\section{Infinite / infinite (II) group MEA design process}

II group MEA design process stages are given in Figure 2. II group, one of its expressions about planning processes, focused primarily on researching the internet and other printed (such as science journals) sources and then preparing a question pool consisting of problems in different styles. Their next plan is to select a problem from this problem pool according to the conditions of the region where they will implement the MEA activity. It was stated that the issue they will pay attention to in this process will be " o create a problem that 
children will encounter in their environment". In the last stage of the plan, it was considered to apply the MEA according to the context decided, evaluate the result, make the arrangement, and if the desired effect is not achieved, a new MEA process will be started.

II group members emphasized that modeling activity should include high-level thinking processes such as "critical thinking, questioning and decision making". The characteristics of the activity questions were defined with the statement "The roots of the questions should be prepared in a way to question the solutions of the students, to verify and check the results". However, the importance of MEA's suitability to real life was determined by the expression "The first and most important of our criteria in the context of modeling efficiency is the principle of reality." In addition, II group members stated compliance with other MEA principles, such as self-assessment, was among the features that activities should have.

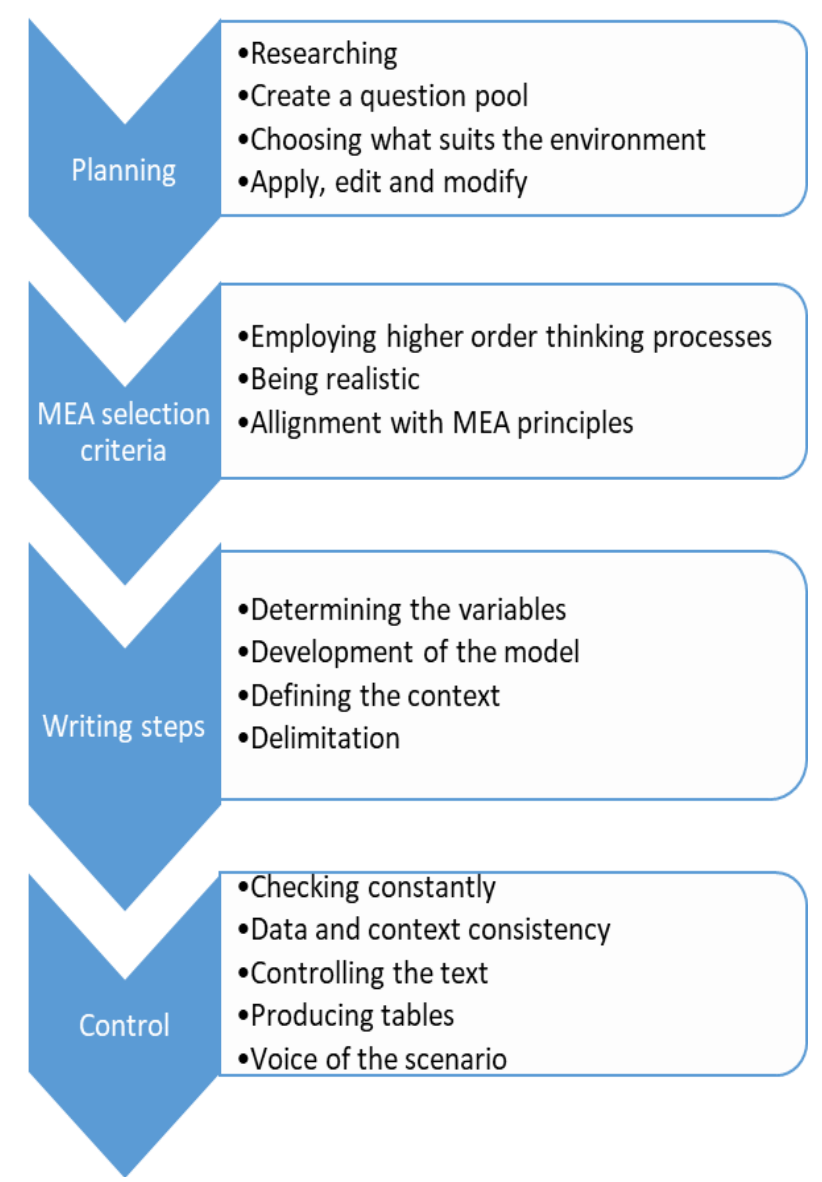

Figure 2. Infinite / infinite group MEA design process

When the process of writing MEA of the II group was examined, first of all, within the context of the problem in the MEA, they considered "the lighting problem as a subject and [They] went to K .. S ... [a business] in Kastamonu." Then they decided which variables to consider when writing questions. In the next step, group studies were carried out on how a model (formula) should be used for the solution process of the MEA created: "We wrote a formula that includes variables such as lighting, types of light bulbs, the size of the space". In addition, they included definitions of concepts such as "lumen, lux", which students thought they would not know, in the problem scenario. In the last stage, MEA activity was created within certain limits, taking into account the variables and solution processes. 
Regarding the post-writing control phase, II group members said, "Actually, our controls were constantly performed at every stage. In our preliminary research, while we were writing and using the model, the controls were made by each of us and arrangements were added" and they provided the information that the control phase was carried out continuously, not at the end point. However, the compatibility of the data they will provide and the results to be achieved in the problem with their real life equivalents was considered by the II group members as one of the control criteria. At this stage, it was thought that presenting the data in a table would contribute to the students to be more understandable and the arrangement was made. They also stated that by making arrangements in the text to ensure the student's interest, "we tried to create a warm atmosphere as if we were chatting with the student" and that they changed the communication tone of the story. Finally, the controls in the text were made and the expressions causing the complexity were removed and a language expert was helped in this direction: "We also had a middle school Turkish teacher have the text checked."

When the MEA activity, named Lighting Cost, of the II group is analyzed in the context of modeling principles, the lighting problem of a local enterprise in Kastamonu is emphasized and the problem situation is defined with real life data (Appendix 2). In this context, it has been found suitable for the principle of reality. In the II group activity, there was no statement for students to review what they did in the process, and expressions included in the problem were not found clear and understandable for middle school students: "Lumen: Total light output emitted by a bulb (the higher the lumen the bulb, the brighter the light), Watt: The amount of energy consumed by a bulb. (That is the value reflected in the electricity bill.)". Therefore, the MEA is considered as "not suitable" for the self-assessment principle. Real-life data and different variables were used in this activity, and asking for help in "choosing which bulb type with low cost" contributes to conformity with the modeling principle. However, there is no statement that reveals the expectation of creating a model. In this context, lighting cost MEA design has been evaluated partially in accordance with the model construction principle. Moreover, this activity did not include an expression explaining the process, except for the students' requesting an e-mail for the result. In this direction, the efficiency has been evaluated partially in accordance with the construct documentation principle. Considering the usability of the model to be employed in the solution of this problem in problem solving including similar situations, the model was evaluated in accordance with the generalization principle.

\section{Pythagorean group MEA design process}

Pythagorean group MEA design process stages are given in Figure 3. As the primary target in MEA design planning, the Pythagorean group aimed to find an activity that "the student can encounter" in real life. In this direction, they pointed out the need for research from different sources such as the internet and textbooks. At the planning stage, group members aimed to carry out this activity over a certain data set. At the last stage of the plan, they expressed their thoughts on an activity design that would include the purpose of "using data and improving processing skills" during the MEA.

Pythagorean group members emphasized the principle of "reality" as an indispensable element of such activities as "the student does not want to be in a scenario and does not get busy". They also stated modeling activities should be suitable for the readiness of the students in terms of both cognitive and affective domains. The statement of "Sometimes we cannot see the math in the next generation questions [for the high school placement exam]. It is not clear which achievement he wants. Mathematics in daily life should be seen clearly in such activities" explains the necessity of questions to reveal the relationship between daily life and mathematics in the program. Finally, Pythagorean group members stated that the questions should be versatile, including universal values such as honesty, truthfulness, and responsibility, and different level intellectual processes, apart from emphasizing mathematics and real life. 
When the process of writing MEA of the Pythagorean group was examined, they first stated that they entered the research process after they decided to connect (Facebook): "We conducted research from local and foreign sites". Following their research, they entered the process of creating and editing the data set, as determined in their design plans: "We reached Facebook data between 2013-2019." Afterwards, the act of writing an MEA scenario by running the data set in accordance with the context they decided on was realized. Regarding the postwriting control phase, the Pythagorean group members stated that "we made changes in a few of the data in order to comply with the MEA principles", it is understood that they checked the compliance of the activity they designed in the control phase with the MEA principles and made adjustments in the data accordingly. In the control phase, the solution process of the MEA was also realized and the deficiencies related to the variables were eliminated, if any. Finally, data and context-related controls for validation of the model employed in the MEA were carried out by the group members.

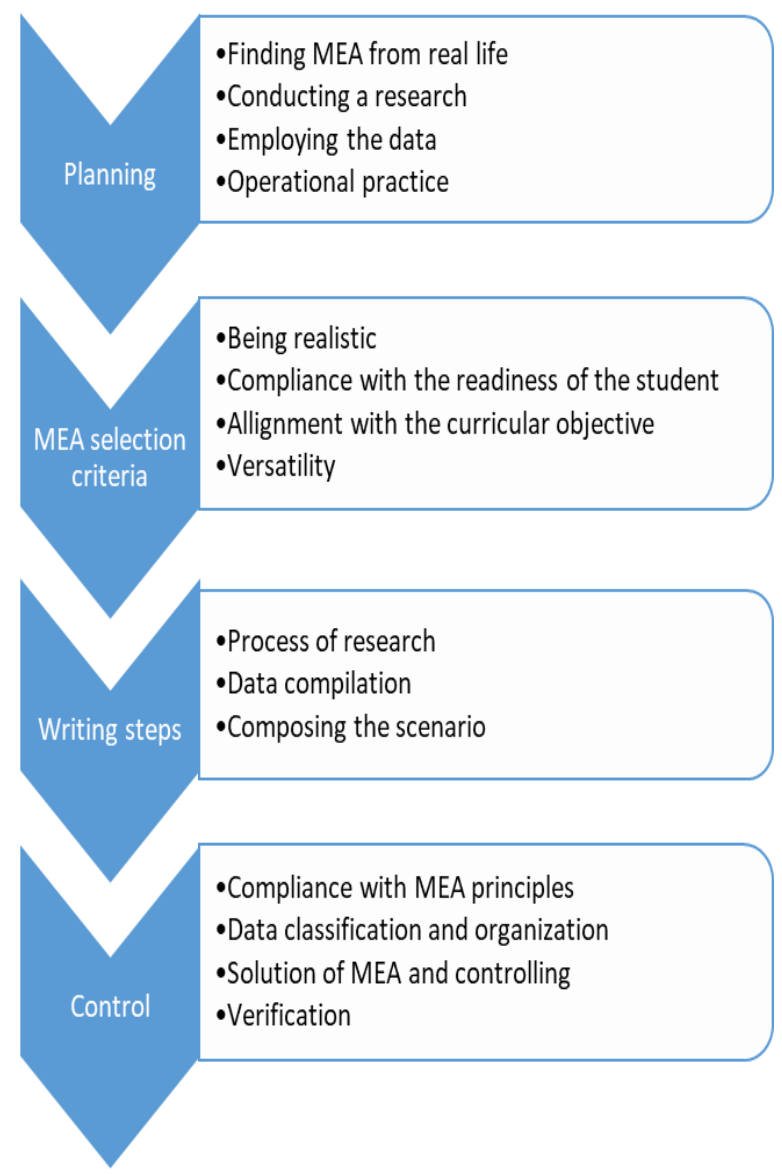

Figure 3. Pythagorean group MEA design process

When the Facebook use activity prepared by the Pythagoreans group is analyzed in the context of the MEA activity modeling principles, the problem situation is related to a social media organization that students frequently encounter in real life, and real data were used in 23 of 25 quarters. Minor changes were made by the Pythagorean group considering the student level in 2 quarters. In this case, the problem situation has been slightly removed from the real data (Appendix 2). In this context, it has been found partially in accordance with the principle of reality. In the Facebook activity, the data were expressed clearly and in accordance with the students' levels. However, there is no statement for students to review what they have done in this process. Therefore, this activity is partially in line with the self-assessment principle. In this 
activity, the way (model) used in the process of finding the annual average user increase amount by using the data of Facebook user numbers in 2029 is requested. However, the statement "... they want you to create a table giving the number of Facebook users similar to the table above" directs the students to create a model. In this direction, the efficiency has been evaluated in accordance with the model construction principle. Also, "Please inform our researchers by email which way you used in your studies." With the statement, the students were asked to express their opinions about their solutions and to write a document to the relevant unit. Therefore, the activity fully complies with the principle of construct documentation. Since the model to be used in the solution of this problem can be used by others for similar purposes, the model has been evaluated in accordance with the generalization principle.

\section{Selective Permeates (SP) group MEA design process}

SP group MEA design process stages are given in Figure 4. As in other groups, SP group members also prioritized research in their planning for MEA design processes: "We planned to do research first in order to decide on the modeling activity. We decided to do the research on the contents of the lessons we took, the resources [in these lessons] and the internet. In the next step, they planned to write questions. "We planned to create alternative scenarios while writing questions." It is understood that SP group members plan to make a decision from a pool of questions. However, they made it their next goal to determine what kind of model they will use based on the decided question. In addition, SP group members included the improvement of the MEA design with solution-control-regulation cyclic phases in the planning process.

SG group members emphasized that among the features of the modeling activity was inclusion of the high-level intellectual processes such as making comparisons to the student, choosing among possible situations and making decisions. However, with statements such as "Modeling activities should include different representations, care about using mathematical tools such as a ruler, and provide the opportunity to make associations between units and real lengths", it was pointed out that the MEA activities work out mathematical skills. As emphasized by other groups, it is very important that the MEA is taken from the student's real life context: "It is very important that the student presents a section from his own life." However, it was stated that MEA should provide students with different solution options with different data: "We thought that problems that present only one solution and one type of data in mathematics did not benefit. The modeling activity should allow for different solutions. "

The first step of MEA writing of SP group was to find the draft scenario idea and create the lines by determining the borders of the activity with the statement "When we found a house design that is interesting to design, has a structure that we can accept as a unit and has geometric shapes that will facilitate the calculation." as they have realized. Afterwards, they made researches in order to determine the variables that will take place in the context of the problem and to determine the values of these variables: "As a result of the research we conducted on the internet and from the tradesmen, we determined various variables such as climate, quality and decoration, we reached data showing the relevant costs and values." In the last stage, the writing stage of the MEA activity was completed by bringing together the scenario context, variables and values of these variables.

SP group members' control of MEA design included MEA principle compliance, context-concept compatibility, compliance with modeling steps and text compliance. The given expression emphasized compliance with modeling principles: "[Referring to the modeling competence training process] We learned the basic principles of modeling in our lesson. We checked the compliance of the activity we wrote with these principles. " Moreover, the following statement was given as an example of the arrangement they made in this direction 
“... The place where the triangle house was built was determined as a warm place in winter. However, since we learned that it should be from their own environment and in a way to increase the student's interest in the modeling activity in our lesson, we changed our scenario. Thus, students will choose glass according to the climatic characteristics of their environment. This situation made it a realistic modeling activity. "

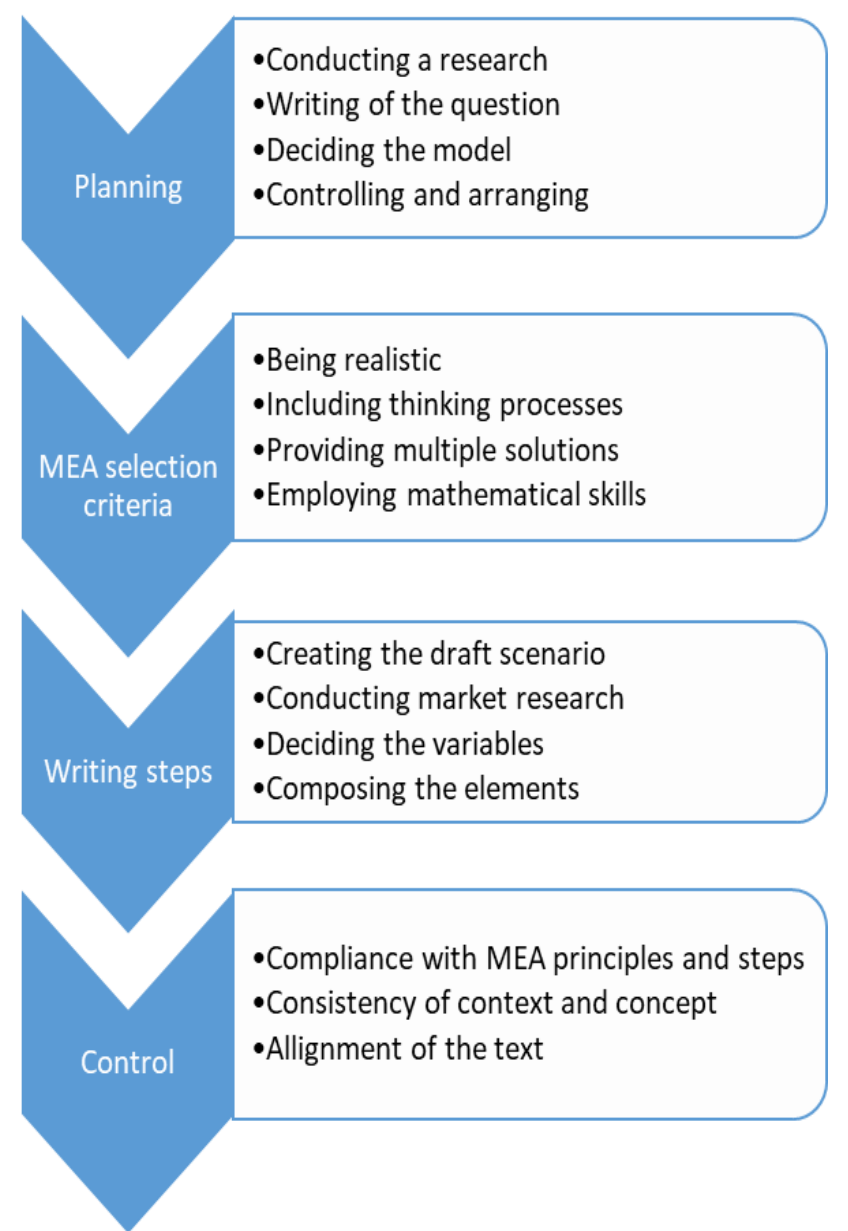

Figure 4. Selective permeable group activity design process

The SP group also reported that they checked the harmony between the context, the variables and the mathematical situation, and that they saw everything compatible. "MEA activity should contain questions appropriate to the modeling processes we handle in our course. The student must identify important variables, write, solve and check the model. We made sure that each of these topics was covered at the modeling event." At this stage, finally, controls and arrangements were made for spelling mistakes and comprehensibility of the expressions used in the text: "These are secondary school students and when the activity is long, the sentences should be well expressed and understandable. So we read it over and over, made some minor changes and finalized it. "

When the glass house MEA prepared by SP group is analyzed in the context of modeling principles, the problem situation is an activity prepared in line with the home design context used and the cost data obtained from real life researches (Appendix 2). At the same time, the fact that the problem will be solved in the context of Kastamonu allows students to add an element from their own lives. In this context, it has been found in accordance with the principle of reality. In the Glass House activity, the data were expressed clearly and in accordance with the students' levels. However, there is no statement for students to review what 
they have done in this process. Therefore, this activity is partially in line with the selfassessment principle. At the event, "... using the table data below, you will make a suggestion that will give the most appropriate glass option and issue a cost report." Although the statement does not emphasize the students' creating models, problem solving requires the use of a model. In this context, the SP group design has been evaluated partially in accordance with the model construction principle. In addition, in this activity, students are asked to document how they think about the solution process and to send their "suggestions to Mehmet Master in letter". Therefore, the activity fully complies with the principle of construct documentation. Since it is taken into consideration that the model to be employed in the solution of this problem can be used for similar purposes, the Glass House activity was evaluated in accordance with the generalization principle.

\section{Results and Discussion}

PMTs' MEAs have been analyzed within the design processes planning, activity determination, writing and control stages. According to the results obtained, there are differences in the modeling processes of prospective teachers in general. Berry and Houston (1995) listed the mathematical modeling process in a linear fashion: understanding the problem, choosing variables, setting up the mathematical model, solving the mathematical problem, interpreting the solution, validating the model, developing the model for other problems and preparing a report. On the other hand, Doerr (1997) defines a nonlinear mathematical modeling process and handles the components cyclically in the form of encountering and defining the real-life problem situation, obtaining data and information, deciding and evaluating the model and process, making interpretation and reconstruction. Özer Keskin (2008) re-adapted the mathematical modeling processes defined by Berry and Houston (1995) and Doerr (1997) and included the stages of understanding the real-life problem, choosing variables, creating a mathematical model, solving, interpreting and verifying it. Although the stages determined by Özer Keskin (2008) do not include the necessity of linearity, it was stated that the process should be reviewed at the points of difficulty and the relevant stages should be repeated when deemed necessary. As can be understood from the explanations above, it is striking that there is no rigid chain of processes in order to achieve the goal in activities related to the mathematical modeling process (Blum \& Niss, 1991; Crouch \& Haines, 2004; Lesh \& Doerr, 2003). In this respect, the differences that occur in the ways PMTs follow in MEA design processes can be considered normal.

The conducting research process draws attention first in the planning of MEAs. PMTs emphasized the necessity of researching different sources (internet, textbook, etc.) in order to determine the correct activity in this direction, that MEAs are activities involving different types of intellectual and cognitive processes. The necessity of MEAs to be related to daily life is one of the highlights in planning. In addition, planning different scenarios and question contexts was also taken into account in order to reach the right design. The following stages are also taken into of controlling the conformity with the basic principles of modeling, whether the determined model is provided and its applicability in different situations. Considering the modeling cycle, the elements that PMTs have included in their planning should be considered important. Lesh and Doerr (2003) emphasize the necessity of starting the mathematical modeling process with an activity related to real life. In this step, it starts with the process of defining a problem that can be solved in the real world, and variables and their importance are determined in line with this context. The next steps include setting up the model, executing the solutions, and evaluating the significance level of the solution for the problem situation. In the last stage, the evaluation of solutions and predictions in the context of the real world is done in the context of the validity and usefulness of the model (Lesh \& Doerr, 2003). In this direction, the fact that PMTs take modeling processes into account in their planning, planning the most appropriate activity 
(creating a pool of questions, offering different solutions, including different intellectual processes) reveals the usefulness of the training process.

The next stage of the MEA design process, the phase of determining the features of the activity, PMTs emphasized inclusion of high-level thinking processes (such as problem solving, critical and creative thinking). Mathematical modeling competencies are a complex structure that includes different intellectual processes in the process of transition from real life to a mathematical model and then validation of the model in real context (Borromeo-Ferri, 2010). It is expected that the modeling activities that will be included for the development of these competencies in the student include high level intellectual processes (Blum \& Kaiser, 1997). Similarly, PMTs emphasized the necessity of providing modeling principles in modeling activities. According to Stillman (2012), the difference of modeling activities from application activities is the process of discovering mathematics that can help in solving the problem. Longterm studies have defined the basic principles representing real life situations (Lesh et al., 2000) and it is emphasized that these teaching-oriented principles should be adopted in the process of designing MEAs (Lesh et al., 2000).

Another issue emphasized by the groups of PMTs regarding the activity characteristics in the modeling process is the compatibility of modeling activities with the curricular outcome. Modeling activities provide a depth of mathematical knowledge through mathematization, as well as using previous learning (Yoon et al., 2010). However, there are different opinions between mathematical modeling activities and the relationship between learning mathematics. While Chinnappan (2010) considers MEAs as a tool that demonstrates and develops the relationship of a certain mathematical content, Blomhoj and Jensen (2007) consider mathematical modeling activities as a purpose for realizing mathematical learning. Although the relationship between mathematical achievements and models is important in both perspectives, it is expected that mathematics course outcomes in MEA designs should be examined in terms of harmony (Stillman, 2012).

The groups also discussed the relativity of the activities to the student, including visual elements, offering multiple solutions and having a mathematical problem nature. According to Fox (2006), mathematical modeling activities should be prepared around themes that are important for children and that are of interest. Thus, it is possible to establish a link between the problem and their personal interpretations. However, MEAs should contribute to the explanation and comprehensibility of the problem with external representations (pictures, diagrams, etc.) and include understandable expressions (Borromeo-Ferri, 2014; Fox, 2006; Lesh et al., 2000). Among the qualifications of MEAs, it has been emphasized in the literature that these activities should create mental complexity in the student, that is, they should show a real problem feature (Borromeo-Ferri, 2014). Based on these results, it can be said that the activity characteristics that pre-service teachers determined in the MEA design process are compatible with the relevant literature.

\section{Future Trends}

The results of the current study determined that the groups used similar processes, although there were some differences in the design writing stages of the MEA. The writing stages proceeded as determining the context of MEA, deciding on variables and assumptions, writing the scenario and adding visual elements. In the control phase, among the factors that the groups paid attention to were compliance with MEA principles, text control, visual arrangement, and realization of solution stages (model and data compliance). According to the results obtained, there are differences in the modeling processes of prospective teachers in general. In the literature, different processes regarding modeling processes have been discussed 
and a complete consensus has not been achieved. It is striking in other studies that there is no rigid chain of processes to achieve the goal in activities related to the mathematical modeling process. Considering the suitability of the pre-service teachers' designs with the modeling principles and their own modeling competencies, it is recommended that the differences in the MEA design processes are met as usual.

\section{References}

Arcavi, A. (2002). The everyday and the academic in mathematics. In M.E. Brenner and J. N. Moschkovich (Eds.), Every day and academic mathematics in the classroom, (pp. 1229). Virginia: National Council of Teacher of Mathematics.

Aydın-Güç, F (2015). Examining mathematical modeling competencies of teacher candidates in learning environments designed to improve mathematical modeling competencies. (Unpublished doctoral dissertation). Karadeniz Technical University, Institute of Education Science, Trabzon.

Baki, A., \& Aydın-Güç, F. (2014a). Matematik öğretmeni adaylarının gerçek yaşam bağlamlarını ele alma yaklaşımları [Approaches of prospective mathematics teachers to real-life contexts]. 11. National Education of Science and Mathematics Congress. Çukurova University, Adana, Türkiye.

Baki, A., \& Aydın-Güç, F. (2014b). Pre-service mathematics teachers' misconceptions on the mathematical model validation process. International Teacher Education Conference, Sharjah, United Arab Emirates.

Bengtsson, M. (2016). How to plan and perform a qualitative study using content analysis. Nursing Plus Open, 2, 8-14.

Berry, J., \& Houston, K. (1995). Mathematical modelling. Bistrol: J. W. Arrow smith Ltd.

Blomhoj, M., \& Kjeldsen, T. H. (2006). Teaching mathematical modelling through project work. The International Journal on Mathematics Education, 38(2), 163-177.

Blomhoj, M., \& Jensen, T. H. (2007). What's all the fuss about competencies? Experiences with using a competence perspective on mathematics education to develop the teaching of mathematical modelling. In W. Blum, P. L. Galbraith, H. W. Henn, and M. Niss (Eds.), Modelling and Applications in Mathematics Education (pp. 45-56). New York: Springer.

Blum, W., \& Kaiser, G. (1997). Vergleichende empirische Untersuchungen zu mathematischen Anwendungsfähigkeiten von englischen und deutschen Lernenden (unpublished document).

Blum, W., \& Niss, M. (1991). Applied mathematical problem solving, modelling, application, and links to other subjects-state, trends, and issues in mathematics instruction. Educational Studies in Mathematics, 22(1), 37-68.

Borromeo-Ferri, R. (2010). On the influence of mathematical thinking styles on learners' modeling behaviour. Journal für Mathematikdidaktik, 31(1), 99-118.

Borromeo-Ferri, R. (2014) Mathematical modeling - the teacher's responsibility. In B. Dickman \& A. Sanfratello (Eds.), Proceedings from the Teachers College Mathematical Modeling Oktoberfest (pp. 26-31). New York: Teachers College Columbia University.

Bukova Güzel, E., Tekin Dede, T., Hıdıroğlu, Ç. N., Kula Ünver, S., \& Özaltun Çelik, A. (2016). Matematik eğitiminde matematiksel modelleme: Araştırmacılar, eğitimciler ve ögrenciler için [Mathematical modeling in mathematics education: For researchers, educators and students]. Ankara: Pegem Academy.

Busse, A. (2005). Individual ways of dealing with the context of realistic tasks-first steps towards a typology. The International Journal on Mathematics Education, 37(5), 354360.

Chinnappan, M. (2010). Cognitive load and modelling of an algebra problem. Mathematics Education Research Journal, 22(2), 8-23. 
Crabtree, B. F., \& Miller, W. L. (Eds.). (1999). Doing qualitative research. Sage Publications.

Creswell, J. W. (2013). Steps in conducting a scholarly-mixed methods study. DBER Speaker series. University of Nebraska Discipline-Based Education Research Group.

Crouch, R., \& Haines, C. (2004). Mathematical modelling: Transitions between the real world and mathematical model. International Journal of Mathematical Education in Science and Technology, 35(2), 197-206.

Dede, A. T., Hıdıroglu, Ç. N., \& Güzel, E. B. (2017). Examining of model eliciting activities developed by mathematics student teachers. Journal on Mathematics Education, 8(2), 223-242.

Doerr, H.M. (1997). Experiment, simulation and analysis: an integrated instructional approach to the concept of force. International Journal of Science Education, 19, 265-282.

Eysenbach, G., \& Köhler, C. (2002). How do consumers search for and appraise health information on the world wide web? Qualitative study using focus groups, usability tests, and in-depth interviews. BMJ, 324(7337), 573-577.

Ferri, R. B., \& Blum, W. (2013). Barriers and motivations of primary teachers for implementing modelling in mathematics lessons. In Eighth Congress of European Research in Mathematics Education (CERME 8), Antalya, Turkey.

Fox, J. (2006). A justification for mathematical modelling experiences in the preparatory classroom. Proceedings $29^{\text {th }}$ Annual Conference of the Mathematics Education Research Group of Australasia 1, 21-228.

Glesne, C., \& Peshkin, A. (1992). Becoming qualitative researchers. New York, NY: White Plains.

Guba, E. G., \& Lincoln, Y. S. (2004). Competing paradigms in qualitative research: Theories and issues. Approaches to qualitative research: A reader on theory and practice, 17-38.

Herget, W., Jahnke, T., \& Kroll, W. (2001). Produktive Aufgaben für den Mathematikunterricht in der Sekundarstufe I. Berlin, Cornelsen.

Hıdıroğlu, Ç. N., \& Bukova Güzel, E. (2014). Using GeoGebra in mathematical modeling: The height-foot length problem. Pamukkale University Journal of Education, 36(2), 29-44.

Kaiser, G., \& Sriraman, B. (2006). A global survey of international perspectives on modelling in mathematics education. The International Journal on Mathematics Education, 38(3), 302-310.

Lesh, R. A., \& Doerr, H. (2003). Foundations of model and modelling perspectives on mathematic teaching and learning. In R. A. Lesh, and H. Doerr (Eds.), Beyond constructivism: Models and modelling perspectives on mathematics teaching, learning and problem solving (pp. 3-33). Mahwah, NJ: Lawrence Erlbaum.

Lesh, R., \& Harel, G. (2003). Problem solving, modeling, and local conceptual developing. Mathematical Thinking and Learning, 5(2-3), 157-189.

Lesh, R., Hoover, M., Hole, B., Kelly, A., \& Post, T. (2000). Principles for developing thoughtrevealing activities for students and teachers. In R. Lesh, and A. Kelly (Eds.), Handbook of research design in mathematics and science education (pp. 591-645). Hillsdale, NJ: Lawrence Erlbaum.

Maaß, K. (2006). What are modelling competencies? The International Journal on Mathematics Education, 38(2), 113-142.

McMillan, J. H. (1996). Educational research: Fundamentals for the consumer. New York, NY: HarperCollins College Publishers.

Merriam, S. B. (1988). Case study research in education: A qualitative approach. Jossey-Bass.

Merriam, S. B., \& Grenier, R. S. (Eds.). (2019). Qualitative research in practice: Examples for discussion and analysis. John Wiley \& Sons.

Miles, M. B. \& Huberman, A. M. (1994). Qualitative data analysis: An expanded sourcebook. Sage.

Ministry of National Education- MoNE. (2005). Curriculum and guide of mathematics in middle school (6-8. grades). Ankara. 
Ministry of National Education- MoNE. (2017). Curriculum of mathematics (Elementary and Middle-School 1, 2, 3, 4, 5, 6, 7, and 8. grades). Ankara.

National Council of Teachers of Mathematics [NCTM]. (1989). Curriculum and Evaluation Standards for School Mathematics. Reston, VA: National Council of Teachers of Mathematics.

National Council of Teachers of Mathematics [NCTM]. (2000). Principles and standards for school mathematics. Reston, VA: National Council of Teachers of Mathematics.

Niss, M., Blum, W., \& Galbraith, P. L. (2007). Introduction. In M. Niss, W. Blum, H. Henn, and P. L. Galbraith (Eds.), Modelling and Applications in Mathematics Education (pp. 3-32). New York: Springer.

Özer Keskin, Ö. (2008). A research of developing the pre-service secondary mathematics teachers mathematical modelling performance. (Unpublished doctoral dissertation). Gazi University, Institute of Education Science, Ankara.

Patton, M. Q. (2002). Two decades of developments in qualitative inquiry: A personal, experiential perspective. Qualitative social work, 1(3), 261-283.

Stillman, G. (2012). Applications and modelling research in secondary classrooms: What have we learnt?. 12 ${ }^{\text {th }}$ International Congress on Mathematical Education Program. COEX, Seoul, Korea. Retrieved from http://www.icme12.org/upload/submission/1923_f.pdf (02 September 2019).

Tekin, A. (2012). Mathematics teachers views concerning model eliciting activities, developmental process and the activities themselves. (Unpublished master's thesis). Dokuz Eylül University, Institute of Education Science, İzmir.

Tekin, A., Hıdıroğlu, Ç.N., \& Bukova Güzel, E. (2010). Öğrenciler matematiksel modellemede birlikte çalıştıklarında hangi yaklaşımları sergiliyorlar? [What approaches students take when working together in mathematical modeling]. IX. Mathematics Symposium, Karadeniz Technical University, 20-22 September 20110, Trabzon, Turkey.

Tekin, A., \& Bukova Güzel, E. (2011). Ortaöğretim matematik öğretmenlerinin matematiksel modellemeye ilişkin görüşlerinin belirlenmesi [Determination of high school mathematics teachers' views on mathematical modeling]. XX. Symposium of Education Science. Mehmet Akif Ersoy University Faculty of Education, 8-10 December 2011, Burdur, Turkey.

Tekin Dede, A., \& Bukova Güzel, E. (2013a). Model eliciting activity: Obesity problem. Elementary Education Online, 12(4), 1100-1119.

Tekin Dede, A., \& Bukova Güzel, E. (2013b). Mathematics teachers' views concerning model eliciting activities, developmental process and the activities themselves. Bartin University Journal of Faculty of Education, 2(1), 288-299.

Umay, A. (2003). Some clues on how much preschool teacher candidates ready to teach mathematics. Hacettepe University Journal of Education, 26, 176-181.

Ural, A. (2014). Examining prospective mathematics teachers' abilities of mathematical modeling. Dicle University Journal of Ziya Gökalp Faculty of Education, 23, 110-141.

Ural, A. (2018). Matematiksel modelleme eğitimi [Mathematical modeling training]. Ankara: An1 Publishing.

Vinner, S. (2007). Mathematics education-procedures, rituals and man's search for meaning. The Journal of Mathematical Behavior, 26(1), 1-10.

Vorhölter, K., Kaiser, G., \& Ferri, R. B. (2014). Modelling in mathematics classroom instruction: An innovative approach for transforming mathematics education. In Transforming mathematics instruction (pp. 21-36). Cham: Springer.

Yoon, C., Dreyfus, T., \& Thomes, M. (2010). How high is the tramping track? Mathematising and applying in a calculus model-eliciting activity. Mathematics Education Research Journal, 22(2), 141-157. 


\section{Appendices}

\section{Appendix 1: MEA Design Process Worksheets}

Hello friends, you are expected to design a MEA with your group at this stage of the training process. What I want from you is to detail your MEA design process by answering the questions given below. Before you start writing your design, formulate your answers to questions 1 and 2. Then, as your processes progress, answer the remaining questions at the end of each process. You can ask me if you have a thought or a question you want to ask while giving your answers.

Group Name:

Group Members:

Explain your modeling activity creation processes in the following headings.

1. What is your plan?

2. What kind of activity should it be? What are your criteria in the context of modeling effectiveness?

3. How did the writing phase take place? How did you decide the context of the problem?

4. How did the control take place?

\section{Appendix 2: The Groups' MEA Designs}

\section{MEA Design of Selective Permeable Group: Glass House}

Mehmet Usta, who lives in Kastamonu, saw the picture of the house in England while surfing the internet and liked it very much. The front and rear facades of this house, which was built underground, were covered with glass and the left and right facades were covered with concrete walls. He thought that he could build such a house with small changes. Mehmet Usta planned to cover the left, right and back facades of the house with stone walls and the front façade, which he considered as the entrance to the house, with glass. However, the glass-covered entrance wall has been requested to have many features such as strength, security, privacy, not being affected much by the weather changes outside, sound insulation and decorative appearance. He thought that having all of these features on the glass wall would force him financially. Mehmet Usta, who allocated a budget of 5200 TL for glass wall covering, made a cost research and discussed this situation with his friend who is interested in glass sales. His friend showed the glass types with their prices and gave him a brochure to help. Your task is to make a proposal to give the most appropriate glass option using the weather conditions of Kastamonu, the area of the glass wall, other possible factors and the table data below, and to issue a cost report. In the form of a letter, you are asked to send your suggestions to Mehmet Usta.

\begin{tabular}{|c|c|}
\hline Tile Between Heat Glass & \\
\hline 16,00 TL per $m^{2}$ & \\
\hline $8,00 \mathrm{TL}$ per $m^{2}$ & \\
\hline Golden Yellow Tile & \\
\hline Brand & Price $\left(m^{2}\right)$ \\
\hline $\begin{array}{l}\text { Heat controlled (Synergy) (In climates where winters are cold and summers are } \\
\text { mild) }\end{array}$ & $250 \mathrm{TL}$ \\
\hline Heat Glass (Comfort) (In climates where winters are warm and summers are hot) & $280 \mathrm{TL}$ \\
\hline Heat Glass (Classic) & $190 \mathrm{TL}$ \\
\hline $\begin{array}{l}\text { Laminated insulating glass (heat insulation, safety, security, soundproofing, } \\
\text { blocking UV rays transmission) }\end{array}$ & $480 \mathrm{TL}$ \\
\hline Jalousie insulating glass (privacy) & $360 \mathrm{TL}$ \\
\hline Jalousie insulating glass Synergy (privacy) & $425 \mathrm{TL}$ \\
\hline Insulating acoustic (soundproofing, safety, security) & $435 \mathrm{TL}$ \\
\hline
\end{tabular}




\section{MEA Design of the Pythagorean group: Use of Facebook}

Facebook, which was established in February 2004, shows a rapid increase in the number of users worldwide. A group of scientists worried about this situation wondered about the number of Facebook users 10 years later and decided to write an article called Facebook and Family Links. Accordingly, they examined the change in the number of users from 2013 to 2019, but they ask for your help, since these results are not sufficient. The researchers want you to calculate the number of Facebook users in 2029 using the table above, and create a table that gives the number of Facebook users between 2019-2030, similar to the table below. You are kindly requested to inform our researchers by e-mail which way you used in your studies.

\begin{tabular}{|c|c|c|}
\hline Year & Quarters & Number of users (million) \\
\hline \multirow{4}{*}{2013} & First & 269 \\
\hline & Second & 272 \\
\hline & Third & 276 \\
\hline & Fourth & 282 \\
\hline \multirow{4}{*}{2014} & First & 289 \\
\hline & Second & 292 \\
\hline & Third & 296 \\
\hline & Fourth & 301 \\
\hline \multirow{4}{*}{2015} & First & 307 \\
\hline & Second & 311 \\
\hline & Third & 315 \\
\hline & Fourth & 322 \\
\hline \multirow{4}{*}{2016} & First & 327 \\
\hline & Second & 332 \\
\hline & Third & 336 \\
\hline & Fourth & 343 \\
\hline \multirow{4}{*}{2017} & First & 348 \\
\hline & Second & 354 \\
\hline & Third & 358 \\
\hline & Fourth & 363 \\
\hline \multirow{4}{*}{2018} & First & 370 \\
\hline & Second & 378 \\
\hline & Third & 379 \\
\hline & Fourth & 385 \\
\hline 2019 & First & 389 \\
\hline
\end{tabular}

\section{MEA Design of the Infinite / Infinite Group: Lighting Cost}

Hello there,

I am Fatih, the owner of a business called Kahve Sokağı in Kastamonu. By popular demand, I decided to open a second branch in Kuzeykent. The pictures you see below are the photos of this cafe. Our cafe, which has been renovated, will be illuminated. Since the renovation process is very costly and I have to keep the lights on for 12 hours a day, I want to make the most costeffective choice that will illuminate all sides adequately and equally as much as possible without consulting any lighting specialist. That's why I have been doing research on the internet for a long time. This job was harder than I thought. I had to know the concepts of lumen, lux and watt in order to decide on the type of bulb. Fortunately, I managed to create a table of these concepts. 


\begin{tabular}{|c|c|c|c|}
\hline Watt & Lux & Lumen & Relationship \\
\hline $\begin{array}{l}\text { The amount of } \\
\text { energy consumed by } \\
\text { a light bulb. (That is, } \\
\text { the value reflected in } \\
\text { the electricity bill.) } \\
1 \mathrm{kw} \text { energy }=0,7 \\
\text { kuruş } \\
1 \mathrm{kw}=1000 \text { watt }\end{array}$ & $\begin{array}{l}\text { Lighting level } \\
\text { Indoor lighting } \\
\text { level should be at } \\
\text { least } 100 \text { lux. }\end{array}$ & $\begin{array}{l}\text { Total light output } \\
\text { emitted by the bulb } \\
\text { (the higher the } \\
\text { lumen bulb, the } \\
\text { brighter the light) }\end{array}$ & $\begin{array}{l}\text { Lux }=\text { lumen / area }\left(m^{2}\right) \\
\text { Area }\left(m^{2}\right)=\text { lumen / lux } \\
\text { In other words, the relationship } \\
\text { between lux and lumen is } \\
\text { related to the area to be } \\
\text { illuminated. }\end{array}$ \\
\hline
\end{tabular}

In the table below, I have created the information on the 3 most suitable LED bulb types for my business:

\begin{tabular}{llll}
\hline Brand & Watt & Price for a Light Bulb & Lumen value \\
\hline Philips & 10watt & 4,25 tl & 1200 \\
\hline UFO & 20 watt & 6,50 tl & 1800 \\
\hline Lighty & 28 watt & 8,45 tl & 2800 \\
\hline
\end{tabular}

Which bulb type do you think I should choose with the lowest cost for the lighting I will do in my cafe? I would love to help me with this. Tables will help you with this. I will be glad if you send the result to my e-mail account.

\section{MEA design of the walking death group: Let's eat pizza}

Cem, who lives in Olukbaşı with his family, preferred watching a cooking program rather than reading a book before going to bed and saw pizza in his dreams. When he waked up in the morning, he run to his mother and told his dream to his mother. Gülten Hanım offered him to eat pizza for lunch. Gülten gives Cem the task of ordering pizza and tells him that the pizzas should be ready to reach lunch and that he should decide on the following options considering the budget. In addition, when ordering, you should take into account that "I have an allergy to gluten, you have an allergy to olives, I have a vegetarian type of diet, and you like pizzas with sausage, do not forget to consider these criteria and the cost" and offers the following options:

1) He can buy pizza from the market near the house according to his criteria and cook himself when he brings it home,

2) He can buy or order pizza from PIZZA 37 in the city center according to their criteria,

3 ) He can buy all their ingredients from one of the 3 grocery stores close to their home and make pizza at home.

4) He can evaluate two of the three options above, which are the most appropriate in terms of cost and criteria.

Cem do various researches on his phone and access the following information. Which option does Cem choose to make the right decision in terms of both cost and compliance with the criteria? Please explain.

Ingredients and market prices

\begin{tabular}{llll}
\hline & A101 & Bं் & ŞOK \\
\hline Floor & $2 \mathrm{~kg} 9,25 \mathrm{TL}$ & $10 \mathrm{~kg} 19,95 \mathrm{TL}$ & $5 \mathrm{~kg} 13,50 \mathrm{TL}$ \\
\hline Water & 5 lt $2,50 \mathrm{TL}$ & $5 \mathrm{lt} 2,25 \mathrm{TL}$ & $5 \mathrm{lt} 4,90 \mathrm{TL}$ \\
\hline Cheese & $700 \mathrm{gr} 17,75 \mathrm{TL}$ & $600 \mathrm{gr} 19,95 \mathrm{TL}$ & $500 \mathrm{gr} 17,25 \mathrm{TL}$ \\
\hline Sausage & $290 \mathrm{gr} 7,25 \mathrm{TL}$ & $270 \mathrm{gr} 7,76 \mathrm{TL}$ & $500 \mathrm{gr} 5,75 \mathrm{TL}$ \\
\hline Salami & $250 \mathrm{gr} 9,95 \mathrm{TL}$ & $700 \mathrm{gr} 15,95 \mathrm{TL}$ & $250 \mathrm{gr} 7,95 \mathrm{TL}$ \\
\hline Olive & $950 \mathrm{gr} 11,95 \mathrm{TL}$ & $1 \mathrm{~kg} 12,45 \mathrm{TL}$ & $800 \mathrm{gr} 12,95 \mathrm{TL}$ \\
\hline Salt & $1500 \mathrm{gr} 1,80 \mathrm{TL}$ & $750 \mathrm{gr} 2,99 \mathrm{TL}$ & $750 \mathrm{gr} 0,90 \mathrm{TL}$ \\
\hline Tuna Fish & $125 \mathrm{gr} 9,95 \mathrm{TL}$ & $100 \mathrm{gr} 5,95 \mathrm{TL}$ & $320 \mathrm{gr} 9,95 \mathrm{TL}$ \\
\hline Mushroom & $400 \mathrm{gr} 3,95 \mathrm{TL}$ & $300 \mathrm{gr} 3,45 \mathrm{TL}$ & $300 \mathrm{gr} 5,00 \mathrm{TL}$ \\
\hline Sesame & $120 \mathrm{gr} 2,95 \mathrm{TL}$ & $75 \mathrm{gr} 6,99 \mathrm{TL}$ & $90 \mathrm{gr} 3,35 \mathrm{TL}$ \\
\hline
\end{tabular}




\begin{tabular}{llll}
\hline Tomato & $1 \mathrm{~kg} 4,99 \mathrm{TL}$ & $1 \mathrm{~kg} 5,90 \mathrm{TL}$ & $1 \mathrm{~kg} 6,99 \mathrm{TL}$ \\
\hline Pepper & $1 \mathrm{~kg} 5,90 \mathrm{TL}$ & $1 \mathrm{~kg} 5,50 \mathrm{TL}$ & $1 \mathrm{~kg} \mathrm{5,95} \mathrm{TL}$ \\
\hline
\end{tabular}

\begin{tabular}{|c|c|c|c|}
\hline PİZZA 37 & Menu & $\begin{array}{l}\text { Gluten Free } \\
\text { Pizza Option }\end{array}$ & Price (TL) \\
\hline \multirow{3}{*}{$\begin{array}{l}\text { P371 } \\
\text { Attractive pizza for one person } \\
\text { (Come and buy campaign) }\end{array}$} & Sausage Lovers & \multirow{3}{*}{ NA } & \multirow{3}{*}{20,99} \\
\hline & $\begin{array}{l}\text { Supers } \\
\text { (Has a Vegetarian Option) }\end{array}$ & & \\
\hline & Classical & & \\
\hline \multirow{3}{*}{$\begin{array}{l}P 372 \\
\text { Special pizza for one person } \\
\text { (ordered home) }\end{array}$} & Sausage Lovers & \multirow{3}{*}{ NA } & \multirow{3}{*}{28,95} \\
\hline & $\begin{array}{l}\text { Supers } \\
\text { (Has a Vegetarian Option) }\end{array}$ & & \\
\hline & Classical & & \\
\hline \multirow{3}{*}{$\begin{array}{l}\text { P373 } \\
\text { Buy } 1 \text { single, buy } 1 \text { free! } \\
\text { (Come and get it) }\end{array}$} & Sausage Lovers & \multirow{3}{*}{ NA } & \multirow{3}{*}{39,95} \\
\hline & $\begin{array}{l}\text { Supers } \\
\text { (Has a Vegetarian Option) }\end{array}$ & & \\
\hline & Classical & & \\
\hline \multirow{3}{*}{$\begin{array}{l}\text { P374 } \\
\text { Buy } 1 \text { single pizza, 2nd single } \\
\text { pizza with } 50 \% \text { discount } \\
\text { (Come and get it) }\end{array}$} & Sausage Lovers & \multirow{3}{*}{ NA } & \multirow{3}{*}{$\begin{array}{l}\text { Price for one } \\
\text { pizza } 30.99\end{array}$} \\
\hline & $\begin{array}{l}\text { Supers } \\
\text { (Has a Vegetarian Option) }\end{array}$ & & \\
\hline & Classical & & \\
\hline \multirow{3}{*}{$\begin{array}{l}\text { P375 } \\
\text { Buy } 3 \text { single pizzas, pay for } 2 \\
\text { single pizzas! } \\
\text { (Order at home) }\end{array}$} & Sausage Lovers & \multirow{3}{*}{ YES } & \multirow{3}{*}{66,95} \\
\hline & $\begin{array}{l}\text { Supers } \\
\text { (Has a Vegetarian Option) }\end{array}$ & & \\
\hline & Classical & & \\
\hline
\end{tabular}

(There is no charge to extract ingredients from pizza)

Frozen Pizza Prices

\begin{tabular}{|c|c|c|c|c|}
\hline Brands & Ingredients & Small & Medium & $\begin{array}{l}\text { Gluten-free } \\
\text { option }\end{array}$ \\
\hline A & Cheddar + sausage & $\begin{array}{l}\text { One for } \\
20.99 \mathrm{TL}\end{array}$ & 29.99 & Yes \\
\hline B & $\begin{array}{l}\text { Salami + Pepperoni }+ \text { tuna }+ \text { cheese }+ \text { mushroom } \\
+ \text { pepper }\end{array}$ & $\begin{array}{l}\text { One for } \\
29.99 \mathrm{TL}\end{array}$ & 39.99 & Yes \\
\hline C & $\begin{array}{l}\text { Broccoli }+ \text { tomato }+ \text { pepper }+ \text { cheddar }+ \text { black } \\
\text { olives }\end{array}$ & $\begin{array}{l}\text { One for } \\
29.99 \mathrm{TL} \\
\end{array}$ & NA & Yes \\
\hline $\mathrm{D}$ & Tomato + mushroom + pepper + cheddar & $\begin{array}{l}\text { One for } \\
21.99 \mathrm{TL}\end{array}$ & NA & NA \\
\hline E & $\begin{array}{l}\text { 1. single person (small) pizza: corn }+ \text { mushroom }+ \\
\text { green pepper }+ \text { red pepper }+ \text { jaleponi pepper }+ \\
\text { mushroom } \\
\text { 2. single (small) pizza: Sausage }+ \text { cheddar }+ \\
\text { salami }\end{array}$ & $\begin{array}{l}1+1 \text { for } \\
49,99 \mathrm{TL}\end{array}$ & NA & Yes \\
\hline
\end{tabular}

